\title{
Atatürk'e Duyulan Güven ve Saygının Güzel Bir Örneği (Boğazlıyan Kaymakamı Kemal Bey'in Annesi Nafia Hanım'ın Atatürk'e Yazdığı Dilekçe
}

\author{
Yrd. Doç. Dr. Erdal AÇIKSES
}

\section{ÖZET}

Birinci Dünya Savaşı'ndan sonra imzalanan Mondros Mütarekesi ile başlayan işgal hadisesine tepkisiz kalarak adeta işgalcilerin her direktifine boyun eğen İstanbul Hükümeti, Ermeni ve Rum komitecilerinin de baskısıyla bir çok insanını kurmuş oldukları Divan-ı Harp Mahkemelerinde idam dahil, ağır cezalara çarptırarak hukuk dışı davranılmıştır.

İstanbul Hükümeti'nin aksine Kuvay-ı Milliyeciler ve onun lideri Mustafa Kemal halkıyla beraber hareket ederek Türkiye Büyük Millet Meclisi'ni kurmuş ve İstiklal Savaşı'nı başlatarak ülkesini işgalcilerden kurtarmıştır. İstiklal Savaşı ve sonrası halkının yanından ayrılmayan Mustafa Kemal ve Türkiye Büyük Millet Meclisi, işgal kuvvetleri, Ermeni ve Rum çeteleri ile İstanbul Hükümetince mağdur edilenlerin yanında olmuş ve uğradıkları haksızlıkları bir dereceye kadar gidermek için bir çok kanun çıkarmış, ayrıca bu kişilerin arkalarında bıraktığı varislerine de sahip çıkmıştır.

Türk Halkının, Mustafa Kemal'e olan güven ve sevgisi her gün artarak devam etmiş ve ona duyulan güvenin bir sonucu olarak her zorluğun üstesinden gelecek bir güç olarak görülmüştür.

Anahtar Kelimeler: Atatürk, Boğazllyan Kaymakamı, Ermeni Meselesi, Tehcir.

*Fırat Üniversitesi Fen - Edebiyat Fakültesi Tarih Bölümü Öğretim Üyesi Elazı̆̆ eacikses@firat.edu.tr 


\title{
A Good Example of Trust and Respect Feelings Towards Atatürk
}

\begin{abstract}
İstanbul Government that showed no reaction against invasion, which started with the Mondros Armistice after the First World War, sentenced many people to death with the pressure of Armenian and Greek Committees. Nationalist Forces and their leader Mustafa Kemal founded Turkish Grand National Assembly and started Independence War by moving with the Turkish people and saved the state from the invaders.

Mustafa Kemal and the National Assembly that never left the Turkish people alone during and after the Independence War supported those who were hurt by the Armenian and Greek committees and enacted a law to cure their pains and they also supported those who were their heirs.

Turkish nation's trust and love towards Mustafa Kemal increased day by day and he is seen as a power that can overcome every difficulty.

Keywords: Atatürk, Head offical of the Boğazliyan District, Armenian Question, Emigration.

Osmanlı Devletini yıkma fikri, yıllarca planlı bir şekilde sürdürülmüş ve son safha olarak da paylaşım düşünülmüştür. Mondros Mütarekesi ile başlayan işgal hareketi ve akabinde oluşan Sevr Antlaşmasıyla paylaşım da şekillenmiştir. Fakat bu plana kaşı yürütülen bir mücadele, uzun yıların ürünü bu planları alt üst edecek bir duruma geleceğini, işgal devletleri yetkilileri de dahil birçok kişi düşünememişti.

İlk anda, birkaç çapulcu isyancı gözüyle bakılan Kuvay-1 Milliye hareketi Mustafa Kemal'in liderliğinde, ona duyulan güvenin eseri olarak bir İstiklal Harbi'ne dönüşmüştü.

İstiklal Harbi işgalcilerle beraber İstanbul yönetimine karşı bir mücadele şeklinde yürütüldü. Adeta işgalcilerle beraber hareket eden Damat Ferit Hükümetleri, halkın üzerinde işgal devletlerinden daha etkili oluyordu. Türk milleti arasına nifak sokarak Kuvay-ı Milliye hareketini engellemeye çalışıyordu. Kuvay-1 Milliye'nin oluşmasında etkili rolü olan kongreleri engellemek için tamimler yayımladı. Birçok görevliyi değiştirerek işlerin zorlaşmasına sebep oldu. Hatta Ali Galip gibi kişileri bu oluşumları engellemek için Anadolu'ya gönderdi.
\end{abstract}


Bu kadarla da yetinmeyen İstanbul Hükümeti, işgal kuvvetlerine yaranmak gayretiyle Divan-1 Harp Mahkemeleri kurarak ${ }^{1}$, birçok görevliyi buraya sevk etmiş ve mahkeme heyetleri de değiştirilerek siyasi kararlarla hapis, hatta idam cezaları dahi verilmiști. Bu kurulan mahkemelere bir çok suçsuz insan çağırılarak sorgulanmış ve mağdur edilmişti. Bu masum insanlardan ilginç biri de, hiç ilgisi olmadığ olmuştur.

Celal Bayar Bey'in hatıralarındaki konuyla ilgili kısımlarda anlatılanlar gerçekten oldukça ilginçtir. Her din ve cemaatten sorgu hakimlerinin emir almışçasına aynı suçlamayı yapmaları ve suçlamalarla ilgili olarak hiçbir belge gösterememeleri de mahkemelerin ortak özelliğidir. Ayrıca bu hususta hiçbir bilgiye sahip olmayan sadece sosyal hizmet ve hayır işleriyle uğraşan Ferit Eczacıbaşı'nın da sorguya alınması, mahkemelerce konuyla ilgisi olmayan bir çok kişinin de mağdur edildiğine kötü bir örnektir. ${ }^{2}$

Boğazlıyan Kaymakamı Kemal Bey de bu mahkemelerde yargılanarak idama mahkum edilen görevlilerden bir tanesiydi. Daha önce de aynı iddialarla suçlanmış, Yozgat İstinaf Mahkemesi'nde yargılanmış ve beraat etmiş olmasına rağmen tekrar mahkeme edilerek suç isnadı aranmıştır ${ }^{3}$.

Mondros Mütarekesi'nden sonra işgal kuvvetlerinin Ermeni ve Rum komitecilere cesaret vermek ve onları kullanmaya devam etmek düşüncesiyle yaptıkları bu girişimlere İstanbul Hükümeti de adeta aracılık etmiştir. Ermeni dernekleri tarafından gazetelere verilen ilanlarla şahitler aranmış ve mahkemeler bu derneklerin isteği doğrultusunda yönlendirilmiştir ${ }^{4}$. İngiliz ve Ermenilerden gelen baskıdan dolayı istifa eden mahkeme başkanının yerine Mustafa Paşa tayin edilmiş ve adeta işgal kuvvetleri ve Ermeni komitecilerin direktiflerine uyarak mahkemeyi onların istediği yönde yönetmiştir's.

Nemrut lakaplı Mustafa Paşa'nın tayininden sonra yapılan mahkemede 8 Kasım 1919 tarihinde alınan kararla ilk defa bir Türk yetkili olarak, Boğazlıyan Kaymakamı Kemal Bey idama mahkum edilmiștir ${ }^{6}$. İngilizler bizzat bu konu ile ilgilenmiş ve Kemal Bey'in idamından sonra Damat

\footnotetext{
${ }^{1}$ Mahkemelerle ilgili olarak Bkz. Azmi Süslü, Ermeniler ve Tehcir Olayl, Yüzünü Y1l Üniversitesi Yayınları No: 5, Ankara, 1990, s. 146 vd.

${ }^{2}$ Celal Bayar, Bende Yazdım, Cilt 5, İstanbul, 1997, s. 35 vd. Bir Kent, Bir Insan (İzmir'in Son Yüzyılı, s. Ferit Eczacıbaşııın Yaşamı ve Anıları) Yaşar Aksoy, Haziran 1986, 360 s., Dr. Nejat f. Eczacıbaşı Vakfı, Toplumsal Belgeler Dizisi Yayınları: 2.

${ }^{3}$ Boğazlıyan Kaymakamı Kemal Bey Olayı ile ilgili olarak, güzel bir çalışmayla konuyu müstakil olarak inceleyen Sayın Necdet Bilgi'nin eseri oldukça doyurucu bilgiler ihtiva etmektedir. Bkz. Necdet Bilgi, Ermeni Tehciri ve Boğazlıyan Kaymakamı Mehmed Kemal Bey'in Yargılanmast, Ankara, 1999.

${ }^{4}$ Alper Gazi Giray, Ermeni Terörünün Kaynakları, İstanbul, 1982, s.529 vd.

${ }^{5}$ Necdet Bilgi, a.g.e., s. $126 \mathrm{vd}$.

${ }^{6}$ Azmi Süslü, a.g.e., s. 148; Alper Gazi Giray, a.g.e., s.531.
} 
Ferit'in güvenilir bir Müttefik ve ayrıca güvenilir bir mahkemenin varlığından bahsedilmiştir? ${ }^{7}$.

Boğazlıyan Kaymakamı Kemal Bey'in idam kararı, Damat Ferit Hükümeti ve İngiliz Muhipleri Cemiyeti'nin gayretleriyle alınan fetva sonrasında padişahın kararı onaylamasını müteakip 10 Nisan 1919 tarihinde yerine getirilmiştir ${ }^{8}$.

İşgal Devletleri ve Amerikan heyetlerinin Mondros Mütarekesi'nden hemen sonra Türk arşivlerinde ve müesseselerinde yoğun bir araştırma yapmış olmalarına rağmen isnat edilen suçlarla ilgili hiçbir belge bulunamamıştır ${ }^{9}$. İstanbul Hükümeti, Boğazlıyan Kaymakamı gibi birçok kişi için daha, batılı devletlerin baskısıyla adeta insan avına çıkmıs ve 1397 kişi hakkında soruşturma açılmışııı ${ }^{10}$.

Bu şekilde suçlanan, hatta bir kısmı bu uydu mahkemelerde hapis veya idama mahkum edilen bir çok kişinin kendilerinin yanı sıra, aileleri de etkilenmiş ve o an yargılamak için bulamadıkları birçok kişi de, Ermeni komiteciler tarafından takip edilerek yargısız infaz şeklinde ( Talat ve Cemal Paşalar gibi) suikast düzenlenerek şehit edilmişlerdir ${ }^{11}$.

Türkiye Büyük Millet Meclisi kurulduktan sonra, adaletli bir kararla; Ermeniler tarafından şehit edilen veya onlar tarafından suçlandığı için İstanbul hükümeti tarafından adaletsiz bir sekilde cezalandırılanların kendilerine ve arkada bıraktıkları ailelerine sahip çıkmış ve işgal kuvvetleri ile beraber hareket etmek yerine milletiyle beraber hareket ederek onlara yardımcı olacak birçok karara imza atmışlardır ${ }^{12}$.

\footnotetext{
${ }^{7}$ Gotthard Jaeschke, Kurtuluş Savaşı ile Illgili Ingiliz Belgeleri, Türkçeye Çeviren: Cemal Köprülü, Ankara, 1971, s. 36-40

${ }^{8}$ Necdet Bilgi, a.g.e., s. 153 vd.; Celal Bayar, a.g.e., s. 68 vd.

${ }^{9}$ Amerika ve Avrupa Devletlerinin çok ısrarlı aramalarına ve araştırmalarına rağmen işgal yıllarında ellerinde bulunan Osmanlı Arşivi dahil olmak üzere Paris, Washington ve Londra arşivlerinde de suç teşkil edecek bir delil bulunamamış fakat Ermeni Patriği ve İngiliz Yüksek Komiserinin verdiği listelerle suçlu avına çıkılmıştır. Bkz. Azmi Süslü, Fahrettin Kırzıoğlu, Refet Yinanç, Yusuf Halaçoğlu, Türk Tarihinde Ermeniler, Ankara , 1995, s. 230 vd.; ayrıca bkz. Bilal Şimşir, The Deportees of Malta and the Armenian Question, Ankara, 1984.

${ }^{10}$ Kamuran Gürün, Ermeni Dosyası, Ankara, 1983, s. 238 vd.; Hasan Kundakçı, Emperyalizmin Kullandı̆̆ı Ermeniler, Ankara, 2001, s. 110-111.

"Tehcirde suçlu addedilerek Ermeni komiteciler tarafından şehit edilen eski görevlilerin çocukları da etkilenmiştir. Bu mağduriyetlerini bir dereceye kadar gidermek düşüncesiyle Türkiye Büyük Millet Meclisi onlara emekli aylığı bağlamıştır. Talat Paşa'nın varislerinin müracaatı üzerine Türkiye Büyük Millet Meclisince aylık bağlanması, bunun güzel bir örneğidir. Bu bilgiler için bkz; Türkiye Cumhuriyeti, Başbakanlık Cumhuriyet Arşivi, No: 030. 18. $01.01 / 016.79 .11$, Tarih: 20. 12. 1925, Say1: 2916. Bkz. Ek: 1-2

${ }^{12}$ Savaş döneminde zarar gören ve şehit edilenlerin ailelerine aylık bağlanması para yardımı yapılması ile ilgili 481 Numaralı Kanun için bakınız; TBMM. Zabıt Ceridesi, Devre II, Cilt 8, s. 632 vd.
} 
Burada Boğazlıyan Kaymakamı Kemal Bey'in asılmasından daha çok, yeni kurulan meclis ve onun Başkanı Mustafa Kemal ve üyelerinin almış olduğu kararlar ve milletinin onlara duyduğu güven ve sevgiden güzel bir örnek vermek için bu yazıları kaleme almak istemiştik. Fakat daha önceki gelişmeler hakkında da bazı bilgiler aktarmamız gerektiğine inandığımız için bu satırları yazdık.

Çünkü bu yazımıza konu olan dilekçe, Boğazlıyan Kaymakamı Kemal Bey'in annesi tarafından Reis-i Cumhur Mustafa Kemal'e yazılmıştır. Türkiye Büyük Millet Meclisi ve Başkanı Mustafa Kemal Paşa, Damat Ferit ve İstanbul yönetimi gibi işgal kuvvetleriyle beraber hareket etmek yerine halkıyla hareket etmiş ve onların hukukuna sahip çıkmış ve hak ve itibarlarını iade etmeye gayret göstermiştir. Kurtuluş Savaşı'ndan sonra da TBMM tarafından çıkarılan yasalarla şehitlerden arkada kalanların mağduriyetleri önlenmeye çalışılmıştır. Meclis çıkardı̆̆ı bir yasayla, Boğazlıyan Kaymakamı Kemal Bey gibi Ermeni komiteleri ve İstanbul Yönetiminden zarar görenlerin "şehitlik" mertebesine ulaştıkları görüşü hakim olmuş ve bütün yazışmalarda da şehit ifadesini kullanmaya özen gösterilmiştir ${ }^{13}$.

Ayrıca çıkarılan bir kanunla şehit olarak kabul ve tescil edilen bu insanların arkada bıraktıkları ailelerine de oturabilecekleri bir emlak verilerek yapılan adaletsizliği bir dereceye kadar gidermeye gayret göstermişlerdir ${ }^{14}$.

Boğazlıyan Kaymakamı Şehit Kemal Bey'in ailesine de 27 Haziran 1926 tarih ve 405 sayılı resmi gazetede yayınlanarak yürürlüğe giren 882 numaralı kanun gereğ $i^{15}$ Eşi Hatice, kızları Müzehher ve Müşerref Hanımlarla oğlu Adnan'a, İstanbul'da değeri yirmi bin liradan fazla bir emlak verilmiştir ${ }^{16}$. Yazımıza konu olan Atatürk'e dilekçe yazan Şehit Kemal'in annesine, o dönemde eşi sağ ve oğlunun vesayetinde olmadığ verilmemiştir.

Şehit Kemal'in annesi Atatürk'e yazdığı dilekçede, (daha sonradan geniş bilgi verileceği üzere) oğlunun eş ve çocuklarına verilen emlakten pay almak için değil, ekonomik olarak zor bir durumda olduğu için yardım istemektedir.

\footnotetext{
${ }^{13}$ Necdet Bilgi, a.g.e., s. $153 \mathrm{vd}$.

${ }^{14}$ Yapılan bağışlarla ilgili olarak bakınız; Erdal Açıkses, "Türkiye Büyük Millet Meclisinin Ermeni Komiteleri Tarafından Şehit Edilenlerin Ailelere Yaptığı Yardımlar”, Ermeni Araştırmaları, Sayı: 6, Yaz 2002, Ankara, 2002, s. 84-94.

is 882 numaralı kanun için bkz. TBMM. Kavanin Mecmuast, Cilt 4, (ikinci basılış), Ankara, 1941, s. 940.

${ }_{16}$ Türkiye Cumhuriyeti, Başbakanlık Cumhuriyet Arşivi, No: 030. 18. 01. 01./ 023. 7. 19 (1), Tarih: 13.02. 1927, Sayı:4716. Bkz. Ek: 3-4-5.
} 
Dilekçe, son derece saygı ve sevgi dolu bir ifadeyle 20.02.1936 tarihinde yazılmıştır. Dilekçe, "Cumhurbaşkanı Büyük ATATÜRK'E”' ifadesiyle başlar ve durumunu arz eden şu ifadelerle devam eder; "Boğazliyan Kaymakamı Şehit Kemal'in annesiyim. Oğlumun şahadetinde kocam sağ, hal ve vaktimiz de yerinde idi. Ŏglumun ailesine milletin bağışladığı mal ve mülkten on para istemeyerek hepsini çocuklarına birakmıştım.

Kocam öldü gayri mübadil olduğumdan bizlere 214 küsur bin lirallk bir mazbata birakt. Bunun esasen 96 bin liralık kısmını - bedel-i icar mazbatası olduğundan -hükümet nazart itibara almadı, kalan resülmaldan tevzi edilen bonoların yïz liralı̆̆ azami (25) liraya satılarak, yirmi sene malımızın Yunanlılar elinde kalmasından kocamın girdiği borçlar ödendi ${ }^{\prime 17}$.

Yukarıda mektuptan aldığımız ifadelerden de anlaşılacağı üzere, “oğluma milletin bağışladı̆̆ı" şeklindeki cümle şehit ailelerine yapılan yardımı, Nafia Hanım devlet, hükümet, millet bütünlüğü çerisinde milletin bir bağışı olarak görmüş ve o şekilde ifade etmiştir. Yirmi yıllık bütün birikimlerinin de göç etmek zorunda kaldıkları için Yunanistan'da kaldığını da belirtmiş̧iir ${ }^{18}$. Ayrıca kendilerinin mübadele dışı tutulduğu için çok az bir parayla yurda göç ettiklerini ve devletin vermiş olduğu mazbatanın da değerinin çok altında bir para tuttuğu için borca girdiklerini ifade etmiştir ${ }^{19}$.

Nafia Hanım mektubunun devamında "şimdi ben on parasızım. Kocamdan kalan ayda (28) lira dul ayllğ̆ da hala o zamandan kalan borçları ödemek için mahcuzdur. Geçen yıl Kamutay'a baş vurarak bir çare dilemiştim. Netice çıkmadı

Yaşayan her insanın tabî̀ hakkı olan: yemek, içmek, ikametgah edinebilmek ihtiyaçlarımı dahi teminden acizim. Daha ödenecek (600-700) lira borcum var ki hiç olmazsa onlar ödenmiş olsa aylı̆̆ı ekmek paramı temin için elimde kalacak." şeklindeki ifadelerle de; Atatürk'ün Yüksek Makamını rahatsız etmeden "Kamutay'a" müracaat ederek çare aramış fakat sonuç alamayınca müracaat etmek zorunda kaldığını saygısından dolayı belirtmek ihtiyacını hissetmiş̧ir. Ayrıca daha rahat bir hayat yaşamak

${ }^{17}$ Nafia Hanım'ın Dilekçesi için bkz; Türkiye Cumhuriyeti, Başbakanlık Cumhuriyet Arşivi, No: 030. 18. 01. 01 / 23. 7. 19 (1). eki 137-75, Tarih: 02.02. 1927, Sayı: 4710; (20. 02. 1936 Tarihli Dilekçe). Bkz. Ek: 6

18 Anadolu'dan göç eden Rumların malları üzerine spekülasyon yapanlar, Balkanlardan Türkiye'ye göç edenlerinde olduğunu ve onlarında çok kıymetli birçok mallarının da, Yunanistan ve diğer Balkan ülkelerinde kaldığını da nedense akıllarına hiç getirmezler. Nafia Hanımın bu hüzünlü ifadeleri, onlara bu hususu da düşünmeleri gerektiği ile ilgili güzel bir örnektir.

${ }^{19}$ Türkiye Cumhuriyeti, Başbakanlık Cumhuriyet Arşivi, No: 030. 18. 01.01/ 23. 7. 19(1). eki 137-75, Tarih: 02. 02. 1927, Sayı: 4710; (20.02. 1936 Tarihli Dilekçe). Bkz. Ek: 6 
için değil borçlarını ödeyebilmek için yardım istediğini ve ödeyememe sebebini de özellikle belirtmiştir.

“ İşte Büyük ATATÜRK, Kemalin anasının bugünkü hali budur. Baş ăgrıtmaktan çok korktuğum halde her derdin ilacını bulan yüksek makamına baş vurduğum için cesaretimi af buyur." şeklinde devam eden mektupta dikkat çeken bir diğer husus ise Atatürk kelimesinin bütün harflerinin her defasında büyük harflerle yazılmış olmasıdır. Ayrıca " her derdin ilacın bulan yïksek makamına" şeklindeki ifadesiyle de Atatürk'e olan güvenini açı bir şekilde dile getirmiştir. Ayrıca kendini rahatsız ettiği için de af dilemeyi ihmal etmeyerek Atatürk'e olan saygısını da bir defa daha ifade etmiştir.

Mektup, "Yetmis yaşımda, hiç alışmadığım halde çekmekte olduğum bu felaket ve sefaletten beni kurtarmak çaresini bulmanı, en derin saygılarımla dilerim Aziz ve büyük ATATÜRK" şeklinde saygı ve dilek ifadeleri ile son bulur ${ }^{20}$.

Boğazlıyan Kaymakamı Şehit Kemal'in annesi Nafia Hanım'ın dilekçesinin akıbeti ise şu şekilde gelişir; Dilekçe aynı gün Başvekalete havale edilir.

Nafia Hanım bir müddet sonra evrakını takip etmek için;

“Sayın Değer (Muhtemelen Saygı Değer yazılmak istenmiş) Başvekil,

Atatürk'e takdim ettiğim bir istidanın yüksek makamınıza havale olunduğunu Cumhur Başkanliğı Özel Büro Direktörlüğ̈̈̈nden haber aldım. $O$ istidada uzun uzun yazdı̆̆ım gibi hakikaten fena bir malî vaziyette ve perişanlık içindeyim. İstidamın neticesi hakkında Lütüfkâr olmanızı dileyerek saygılarımı sunarım."şeklindeki 13.03.1936 tarihinde bir dilekçe daha verir ${ }^{21}$.

Dilekçeye; “Çekmiş olduğu telgrafını 24.2.936 tarihinde 3/316 sayı ile Dahiliye Vekilliğine sunulmuş olduğunu arz ederim.” şeklinde Evrak Müd. imzasıyla bir not düşülerek bilgi verilir.

Bu dilekçedeki ifadelerle daha önce bahsettiğimiz dilekçenin aynı kişiye ait olmasına rağmen aradaki farklılık hemen göze çarpmaktadır. Şöyle ki; bu dilekçede devlet daire ve yetkililerine duyulan saygı hissedilmekle beraber

${ }^{20}$ Dilekçe dönemin okur yazar oranının çok az olduğunun adeta bir belirtisi olan, mühür kullanma geleneğinin bir örneği olarak imza yerine NAFİA şeklinde mühürle mühürlenmiştir. Fakat Bazı Dilekçelerde Nafia şeklinde yazılarak imzada atılmıştır. Adres olarak da "Fenerbahçe Dalyan Sokak no: 8 de Kemalin Anası Nafia" olarak adres belirtilmiştir.

2ı Bu konuda daha geniş bilgi için bkz.: Türkiye Cumhuriyeti, Başbakanlık Cumhuriyet Arşivi, No: 030. 18.01.01/23. 7. 19(1). eki 137-75, Tarih: 02. 02. 1927, Say1: 4710; (13. 03. 1936 Tarihli Dilekçe). Bkz. Ek: 7 
Atatürk'ün makamına yazılan mektup şeklinde kaleme alınmış dilekçedeki samimi sevgi ve saygıyı bulabilmek pek mümkün değil.

Atatürk'e sunulan dilekçe Başvekalete havale edilmiş, Başvekalet de, Başvekil yerine Müsteşar imzasıyla; "gereğinin yapılmasını müsaadelerinize rica ederim" şeklinde bir yazıly 18.03.1936 tarihinde Dahiliye Vekaleti'ne havale etmiştir ${ }^{22}$.

Dahiliye Vekaleti de; Başvekâletin C: 19/3/936 tarih ve 6/924 sayılı yazısına

"Fenerbahçe Dalyan Sokak 8 N.lu evde oturan Eski Boğazliyan kaymakamı şehit Kemalin annesi Nafianın dilekçesi, Kemalin aile ve çocuklarına Hükûmetçe yapılan yardımdan anasının da istifade ettirilmesine müterettip muamelenin yaptmast ricasiyle 28/2/936 tarih ve 1177 sayılı yazı ile Maliye bakanlığına gönderilmiş olduğunu saygılarımla arzederim."; şeklindeki Başvekâlete yazdığı 23.03.1936 tarihli Dahiliye Vekili imzasıyla konu hakkında Başvekâlete bilgi verir ${ }^{23}$.

Dahiliye Vekaleti'ne gelen yazı bir dereceye kadar burada şekil değiştirmiş ve Nafia Hanım'ın oğlu Şehit Kemal'in eş ve çocuklarına bağışlanan maldan pay istemediğini, sadece borçlarını ödeyecek kadar nakdi bir para istediğini özellikle belirtmiş olduğu halde, Dahiliye Vekâleti (önceden çıkan kanunu da bilmediği için olsa gerek) çözümü daha önceden tahsis edilen yardımdan Nafia Hanım'ın da faydalanabilmesi için işlem yapılmasını ister.

Dahiliye Vekâleti tarafından Maliye Vekâleti'ne havale edilen dilekçe, Nafia Hanım'ın Başvekalete verdiği dilekçeye cevap verebilmek için, bu defa da Başvekalet Maliye Vekaleti'ne bir yazı yazarak işlemin sonucunu öğrenmeye çalışır. Ayrıca Başvekâlet Maliye Vekâleti ile yaptığı yazışmaya işlemin gelişmesiyle ilgili bilginin Nafia Hanıma da ulaştırılmasını ister ${ }^{24}$.

Nihayet, Maliye Vekâleti görüşünü 21.05.1936 tarihinde Başvekâlete yazdığı;

${ }^{22}$ Türkiye Cumhuriyeti, Başbakanlık Cumhuriyet Arşivi, No: 030. 18. 01.01 / 23. 7. 19(1). eki 137-75, Tarih: 02. 02. 1927, Sayı: 4710; (19.03.1936 Tarihli Başvekaletin müsvedde yazısı). Bkz. Ek 8

${ }^{23}$ Türkiye Cumhuriyeti, Başbakanlık Cumhuriyet Arşivi, No: 030. 18. 01.01 / 23. 7. 19(1). eki 137-75, Tarih: 02. 02. 1927, Say1: 4710. (Dahiliye Vekaletinin 23. 03. 1936 Tarihli Arzı) Bkz. Ek: 9

23 Türkiye Cumhuriyeti, Başbakanlık Cumhuriyet Arşivi, No: 030. 18. 01.01 / 23. 7. 19(1). eki 137-75, Tarih: 02. 02. 1927, Sayı: 4710; (Dahiliye Vekaletinin 23. 03.1936 Tarihli Arzi). Bkz. Ek: 9

${ }^{24}$ Nafia Hanım'ın Mektubu için bkz; Türkiye Cumhuriyeti, Başbakanlık Cumhuriyet Arşivi, No: 030. 18. 01. 01 / 23. 7. 19(1). eki 137-75, Tarih: 02.02. 1927, Sayı: 4710; (27.031936 Tarihli Başvekil Yerine Müsteşar Adına yazılmış müsvedde yazı). Bkz. Ek: 10 
"Boğazlıyan kaymakamı Şehit Kemalin annesi Nafia tarafından bittakdim Dahiliye Vekâletine havale buyrulan ve taalluku hasebile hazineye gönderilen arzuhal tetkik olundu.

Dilek sahibi oğlunun vefatı sırasında kocasının hali vakti yerinde olduğundan oğlu ve ailesi efradına milletin bağışladığım mal ve mülkten bir şey istemediğini, kocasının ölümile kendisine intikal eden 28 lira dul maaşının iaşesine kâfi gelmediğini, ödenecek 700 lira borcu olduğunu ileri sürerek yardım talebinde bulunmaktadır.

Ŏglunun vefatı strasında kendisi evli ve gayri muhtaç bulunduğundan oğlunun efradı ailesine 882 sayılı kanun hükümlerine göre tahsis edilen emvalden kendisine de hisse verilmesi mezkûr kanun hükümlerine uygun değildir. Bu sebepten kendisine mal tefviz edilmemiş idi. Dilek esasen mal tefevvüzünü istihdaf etmeyip 700 lirallk borcunun tesviyesine medar olacak nakti bir yardımın yapılmasına matuf bulunmasına göre keyfiyyetin yïksek makamlarınca tayin ve takririne müsaade buyrulmasını ve mürsel arzuhalin leffen takdim kılındığını arzeylerim." șeklindeki ifadelerle belirtir ve kararı Başvekâlete havale eder ${ }^{25}$.

Maliye Vekâleti, dilekçenin özünü anlamış ve Nafia Hanım'ın dileğinin bir mal tahsisi veya oğlunun eş ve çocuklarına bağışlanan emlaktan pay almak istemediğini, sadece yedi yüz liralık borcunu ödeyebilmek için nakdi bir yardımın yapılmasın istediğini belirtir.

Başvekâlet, Maliye Vekâletinden aldığı görüşten sonra, Baş Vekâlet Müsteşarı'nın imzasıyla;

“ Reisi Cumhura sunduğunuz 20-2-936 tarihli dilekçenize cevaptır. Ŏglunuz merhum Kemalin ailesi efradına 882 nolu kanun mucibince emval tahsis edilirken siz evli ve gayri muhtaç bulunduğunuzdan size hisse verilmemiş olduğu ve şimdi de ayrılmasının kanun müsait olmadığı Maliye Vekâletinden bildirilmiştir. Tebliğ olunur" şeklindeki bir yazı ile dilekçenin cevabı Nafia Hanıma bildiriliti ${ }^{26}$.

Nafia Hanım'a tebliğ olunan yazıda, oğlunun eş ve çocuklarına daha önce yapılan bağıştan bir hisse verilmesinin, bağışı sağlayan kanunun hükmüne göre mümkün olmadığı bildirilmiştir. Zaten Nafia Hanım dilekçesinde böyle bir pay istemediğini belirtmişti. Fakat nedense yazışmalar hep bu konu üzerine yoğunlaşmıştır. Bu şekilde bir yardımın yapılamayacağı kesinleşmiş

${ }^{25}$ Nafia Hanım'ın dilekçesi için bkz; Türkiye Cumhuriyeti, Başbakanlık Cumhuriyet Arşivi, No: 030. 18.01. 01 /23. 7. 19(1). eki 137-75, Tarih: 02. 02. 1927, Sayı: 4710; (21.05. 1936 Tarihli Maliye Vekili imzalı yazı). Bkz. Ek: 11

${ }^{26}$ Nafia Hanım'ın Mektubu için bkz; Türkiye Cumhuriyeti, Başbakanlık Cumhuriyet Arşivi, No: 030. 18. 01. 01/ 23. 7. 19(1). eki 137-75, Tarih: 02. 02. 1927, Say1: 4710; ( 26. 05. 1936 Tarihli Başvekil Müsteşarı adına yazılmış müsvedde yazı). Bkz. Ek: 12 
olmakla beraber, sonuçta başkaca bir yardım yapılıp yapılmadığı ile ilgili bir bilgiye de ulaşamadık.

Sonuç olarak yukarıda kısaca temas ettiğimiz gibi, Türk halkının Atatürk'e duyduğu güven ve saygıyı her vesile ile dile getirdiği ve isminin geçtiği yazışmalarda dahi ona duyulan sevgi ve saygının adeta yazının özünden daha fazla hissedildiği görülmektedir.

Yukarıda kısaca verdiğimiz bilgilerden de anlaşılacağı üzere; Boğazlıyan Kaymakamı Şehit Kemal'in, bazı iddiaların aksine Ermeni Tehciri sırasında tehcir edilenlerin mallarından bir servet elde etmiş değildir. Çünkü annesinin muhtaç durumu ortadadır. Babası borçlu olarak ölmüştür ve kalan borçlarını annesi ödeyememektedir. Ayrıca çocukları da devletten aldığı yardımla hayatlarını idame etmektedirler.

Ayrıca Birinci Dünya Savaşı ve Milli Mücadele boyunca Rum ve Ermenileri Türk Milletine saldırtarak onların zarar görmesine de sebep olanlar, onlar kadar hatta onlardan daha fazla canından, yerinden yurdundan edilen Türklerin de maddi manevi bir çok zarara uğramalarına sebep olmuşlardır. Bunun en kötü örneği de Boğazlıyan Kaymakamı Şehit Kemal Bey'in annesi, eşi ve çocuklarının durumudur. Bu örneklerde bize gösteriyor ki, Rum ve Ermenileri yine kullanmak için onlarla beraber hareket eden Batı'nın, Rum ve Ermeni iddiaları olarak ortaya çıkarttıkları birçok asılsız olay, ilmi ve tarihi gerçeklerden uzak siyasi söylevlerden başka bir şey değildir.

Bir öz eleştiri yapmak gerekirse, o dönemde de ağır bir bürokrasinin olduğunu söylemek mümkün. 


\section{EKLER}

$$
\therefore:=0
$$
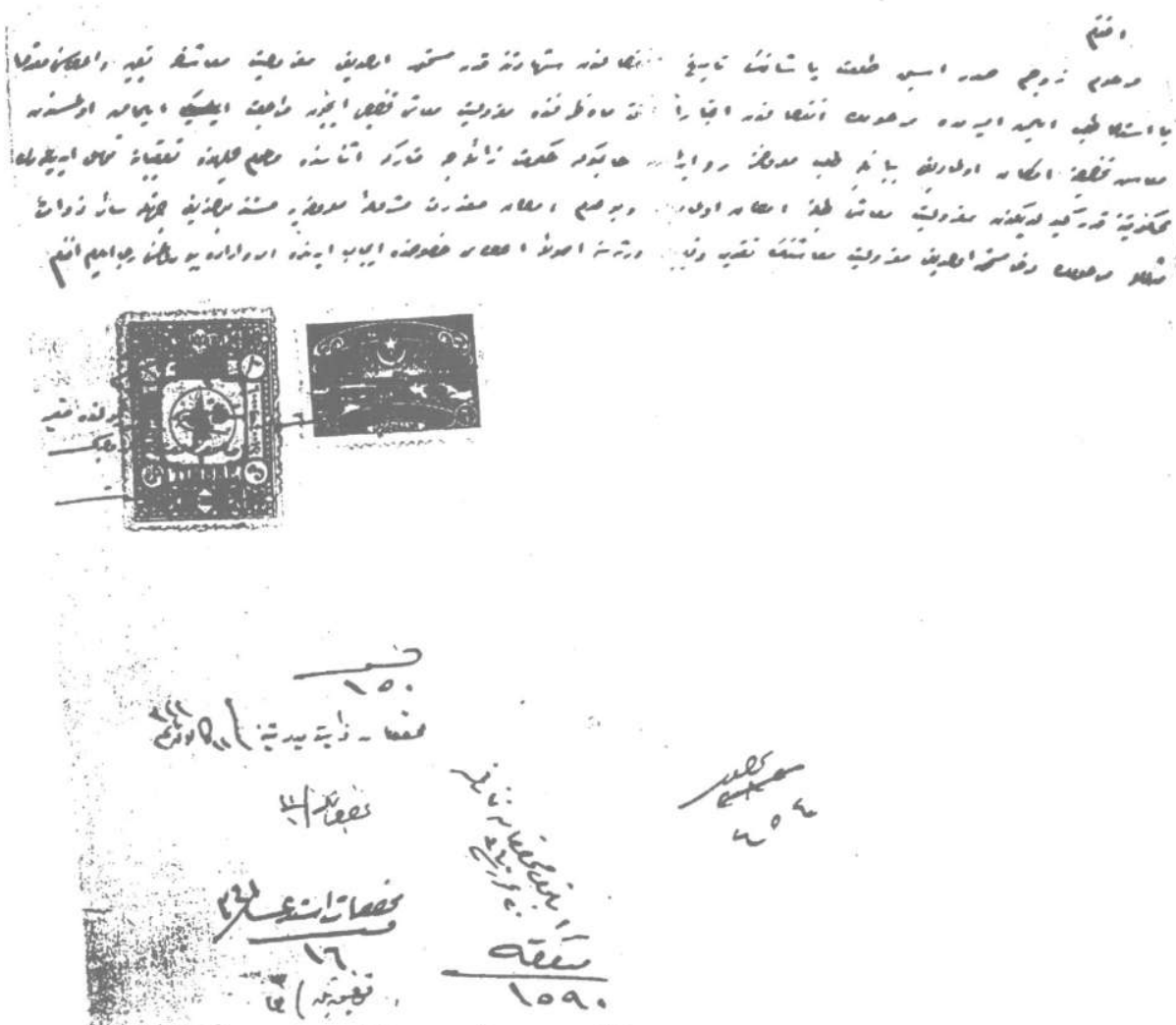

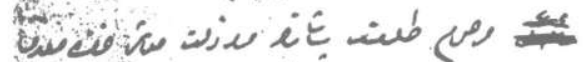

"مان

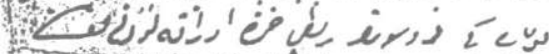
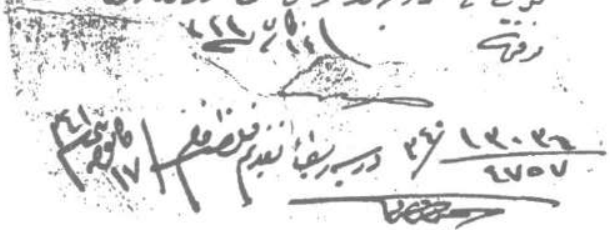

Ek 1- Ermeni Komitelerince Şehit Edilen Talat Paşa'nın varislerinin emekli aylığı bağlanması için yaptıkları başvuru dilekçesi. Türkiye Cumhuriyeti, Başbakanlık Cumhuriyet Arşivi, No: 030. 18.01.01 / 18. 245.140 eki. 245-140, Tarih: 20.12.1925, Say1: 2916. 


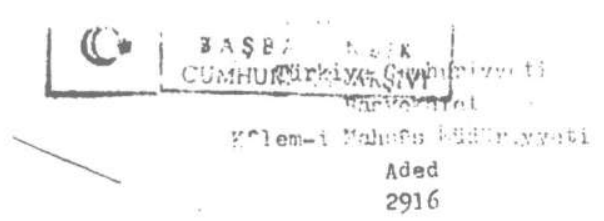

\section{Kararnime}

Mutareke esnasında al eyhinde tr'kibat icrs ol unmasi hasebiyle ma'zul iryet

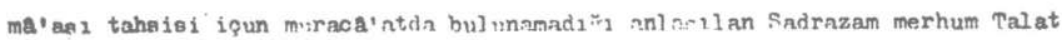
pasa namma tahrisi multagi ma'zuliryet mA'nrinun incisall tarihindan Şahadeł 1 tarihine kadar tahakkuk itdiri.linek surati.yje veressbine i'tasi Malive "ekaletinin 19 yol 34 tarih ve Muhassasatazatiyye 2337 numrolu tezkiresiyle vuku' bulan teklifi izerine, tora Vekilleri Iley'etinin ?n kanunuevvel 341 tarihli ictima'inda tasvib ve $y a^{2}$ ul olunmusdur.

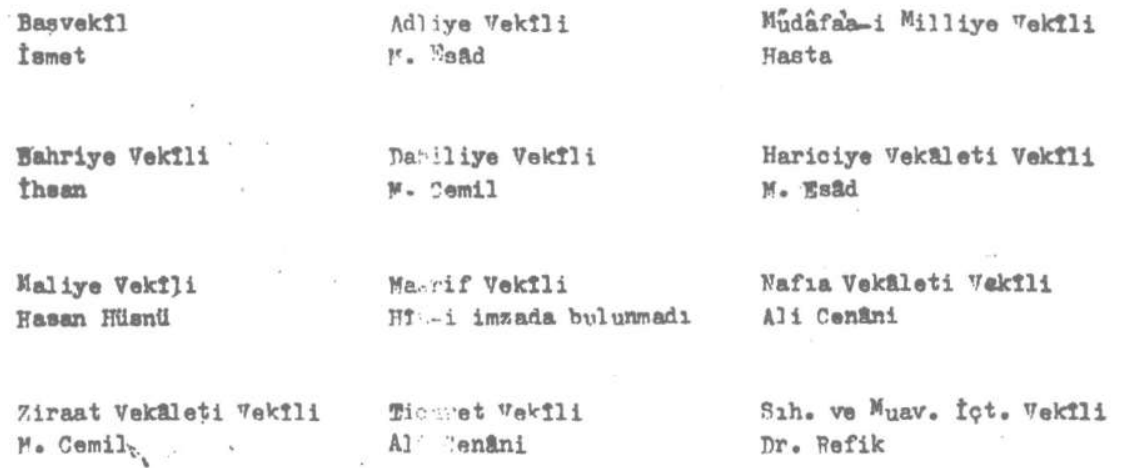

Ek 2- Ermeni Komitelerince Şehit Edilen Talat Paşa'nın varislerinin emekli aylığı bağlanması için İcra Vekileri Heyetince çıkarılan kararname Türkiye Cumhuriyeti, Başbakanlık Cumhuriyet Arşivi, No: 030. 18.01.01 / 016. 71. 11, Tarih: 20. 12. 1925 Sayı: 2916 (2916 sayı ve 20 Kânunevvel 341 Tarihli Kararname). 
Turkiye Cumhuriyyeti

Bagrekalet

Kalem-i Mahsus Múdiriyyeti

Aded 4710

Kararnaిme

Ermeni emval-i metrôkesinden bulunmasi hasebiyle Maliye Vekalet-i Celilesince Evkaf Idaresine devir olunan ve Istanbul tdare Hey'etince yirmibin lira kıymet takdIr idildiği anlaşılan merbat cedvelde muharrer apartmanla hanenin, 31 Mayıs 926 tarih ve 882 numrolu kanun ahkåmına tevikân, Boğazlıyan ka'ımakamı Kemal beyin hfn-i vefatında nakafasiyle mükellef bulundı̆̆ zevcesi Hatice ve kerimeleri Müzehher ve Müşerref hanımlarla mahdumı Adnan bey namlarına tahsis ve temliki, Bvkaf Müdüriyyet-i Umomiyyesinin 2 şubat 927 tarih ve 31667/17 numrolu tezkiresiyle vuka'bulan teklifi üzerine, Iora Vekilleri Hey'etinin 2 Şubat 927 tarihli icitma'ında tasvib ve kabul olunmuşdư. 2 Şubat 927

\begin{tabular}{|c|c|c|}
\hline & & $\begin{array}{l}\text { Reis-icumhur } \\
\text { Gazi M.Kemal }\end{array}$ \\
\hline $\begin{array}{l}\text { Besgvekfl } \\
\text { tsmet }\end{array}$ & $\begin{array}{l}\text { Adliye Vek. } \\
\text { M. Bast }\end{array}$ & $\begin{array}{l}\text { M.Milliyye Vek. } \\
\text { Receb }\end{array}$ \\
\hline $\begin{array}{l}\text { Bahriye Vek. } \\
\text { thsan }\end{array}$ & $\begin{array}{l}\text { Dahiliyye Vek. } \\
\text { M.Cemil }\end{array}$ & $\begin{array}{l}\text { Hariciyye Vak. } \\
\text { Dr.T.Rüş̧tu }\end{array}$ \\
\hline $\begin{array}{l}\text { Malije Vek. } \\
\text { M.Abdilhalik }\end{array}$ & $\begin{array}{l}\text { Maarif Vek.Vak. } \\
\text { Dr.iofik }\end{array}$ & $\begin{array}{l}\text { Nafia Vek. } \\
\text { Behiç }\end{array}$ \\
\hline $\begin{array}{l}\text { Ziraat Vek. } \\
\text { M.Sabri }\end{array}$ & $\begin{array}{l}\text { Ticuret Vek. } \\
\text { M.P.hmi }\end{array}$ & $\begin{array}{l}\text { S h.ve Mua.Ict.V } \\
\text { Dr.Rerik }\end{array}$ \\
\hline
\end{tabular}

Ek 3- Boğazlıyan Kaymakamı Kemal Bey'in varislerine yirmi bin lira kıymetinde belirlenmiş olan emlakin temlikinin kabul edildiğine dair kararname. Türkiye Cumhuriyeti, Başbakanlık Cumhuriyet Arşivi, No: 030. 18. 01. 01 / 023. 7. 12, Tarih: 13. 02.1927, Sayı: 4710 ve 4710 (4710 sayı ve 2 Şubat 1927 Tarihli Kararname). 


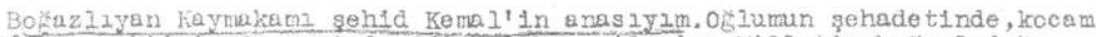

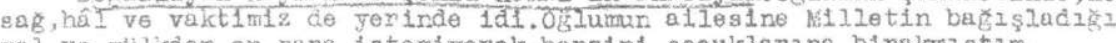
mal ve mulkden on para istemiyerek, hepsini cocuklarana birakmiģtim.

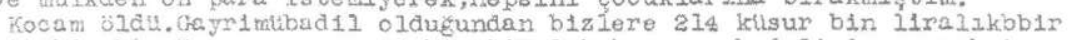
nazbata blyalti. Bumun esasen 96 bin liralik irlsmini-bedol1 icar mazbatas oldukundan-hikûmet nazarl itibara almad., Kalan resilmalden tevz1 od1len Bonoların, vitz liraliéz azam (25) liyaya satilarak, yirmi sene malimizin vunaniliar elinde kalnasindan kocamin girdilel borclar ödondi.

\$indi; ber, an parasizin. Kocamdan kalan aydá (28) lira duj. ayliż da

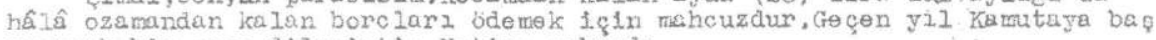
vurarak bir care dilemistim. Netice clkmadi.

Yasayan her insanin tabif hakki olan: jemek, 1 cmek, ikametîhn edinebilmek int1jaclarinz dahi taminder ac1zim.Dahe daenecek (600-700) lima borcum var k1,

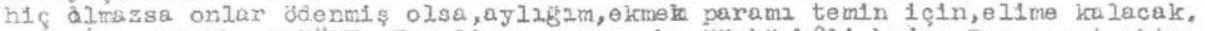

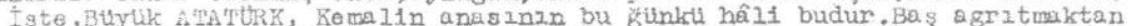

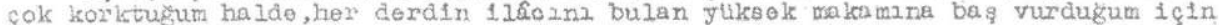
cesaretini of buyur

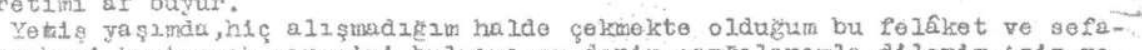
letten beni kurtarmak çaresin1 bulmanz, on derin saygjlarima dilerim, Az1z ve blyitk A TATERK.

Penerbahço Dalyan sokak No 8 de Kemalin anasi: Nafla.
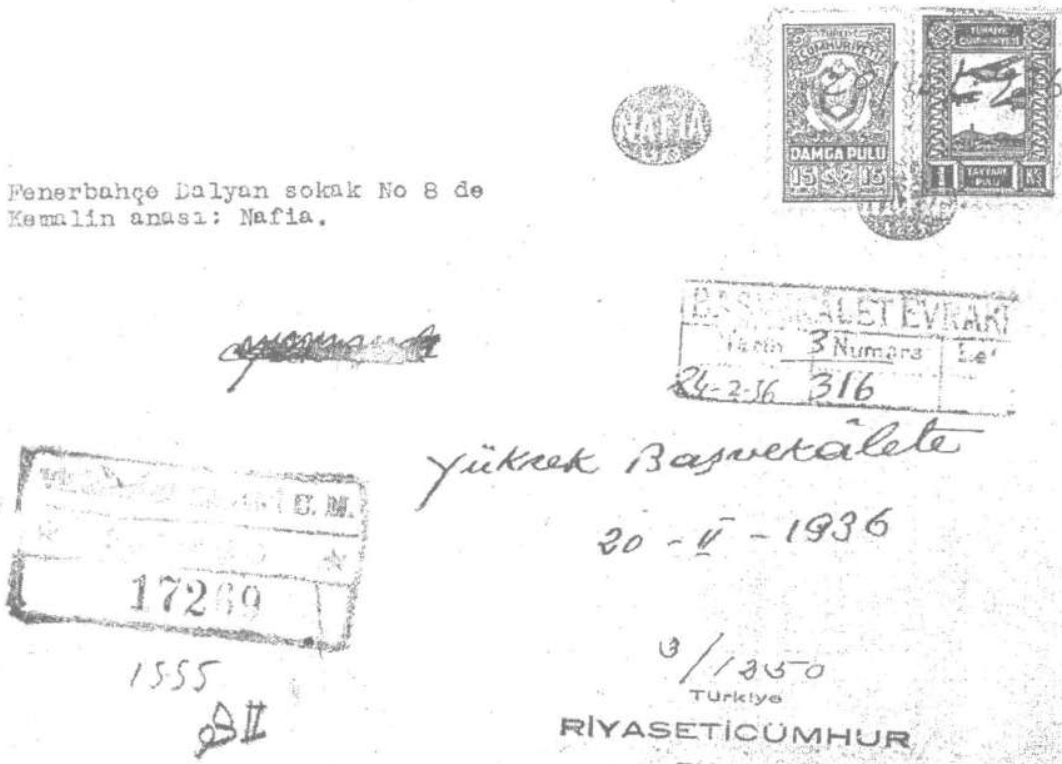

yükeet

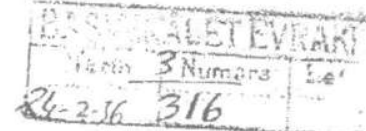

$2<-2.36+316$

sapretalete

$20-4-1936$

$3 / 23 s$

RIYASETICUMHUR

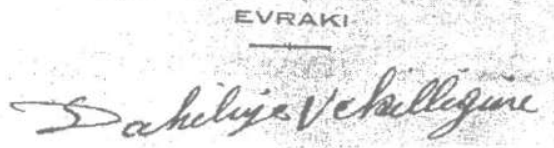

Ek 4- Boğazlıyan Kaymakamı Şehit Kemal' in Annesi Nafia Hanım'ın

“Cumhurbaşkanı Büyük Atatürk'e” başlığıyla yazdığı yardım talebi ile ilgili gerçekten içler acısı durumunu ve Atatürk'e duyulan saygı, sevgi ve güveni gösteren dilekçesi. Türkiye Cumhuriyeti, Başbakanlık Cumhuriyet Arşivi, No: 030. 18. 01. 01 / 23. 7. 19(1). Eki 137-75 Tarih: 02. 02. 1927, Sayı: 4710 (20.02. 1936 Tarihli Dilekçe). 


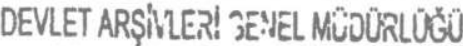

CUMHUURYYET ARSSIVI

$13 / 3 / 936$

Sayan deser Bę vektl, Atatlirk'e takdim ettigim bir istidenun fliksek makaminiza havalo olundüumu Cumur Başkanllobl Ozel Firo Direktorluglinden haber aldum. 0 Istidaida uzun uzun yazdifim gibl hakikaten fena bir mall vazijette, ve perisanlik 1qindeyjm. is stidaman net1cosi hakkanda Iutlifkâx olmanzzl dileyerek saygllarzm sunarzm.

Adres :

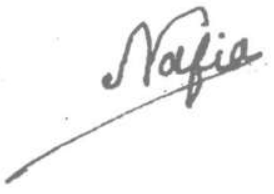

Penerbahçe Dalyan soleak Io : 8'de BobazIIyan kaymakaml sehtd Femal'in annesl Iafia.

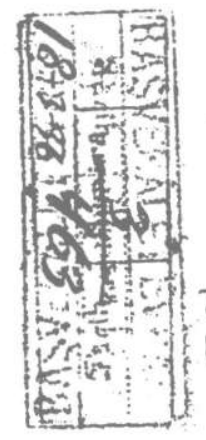

Gersater

$17-3-36$

Cekmis, aldug̃n telgrafme4 . 2,936

tarihinde $\frac{3}{316}$ sayj ile Dahilige

Vekelligin

arzoderim:
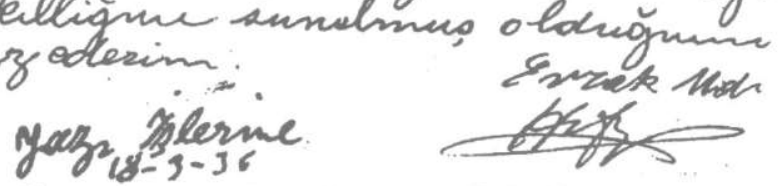

Ek 5- Boğazlıyan Kaymakamı Şchit Kemal'in Annesi Nafia Hanım'ın

Atatürk'e yazdığı dilekçesinin Başvekâlete havalesinden sonra sonucunu takip etmik için Başvekâlete verdiği dilekçe. Türkiye Cumhuriyeti, Başbakanlık Cumhuriyet Arşivi, No: 030 18. 01. $01 / 23.7$. 19(1), eki 137-75 Tarih: 02.02. 1927, Say1: 4710 (13.03. 1936 Tarihli Dilekçe). 


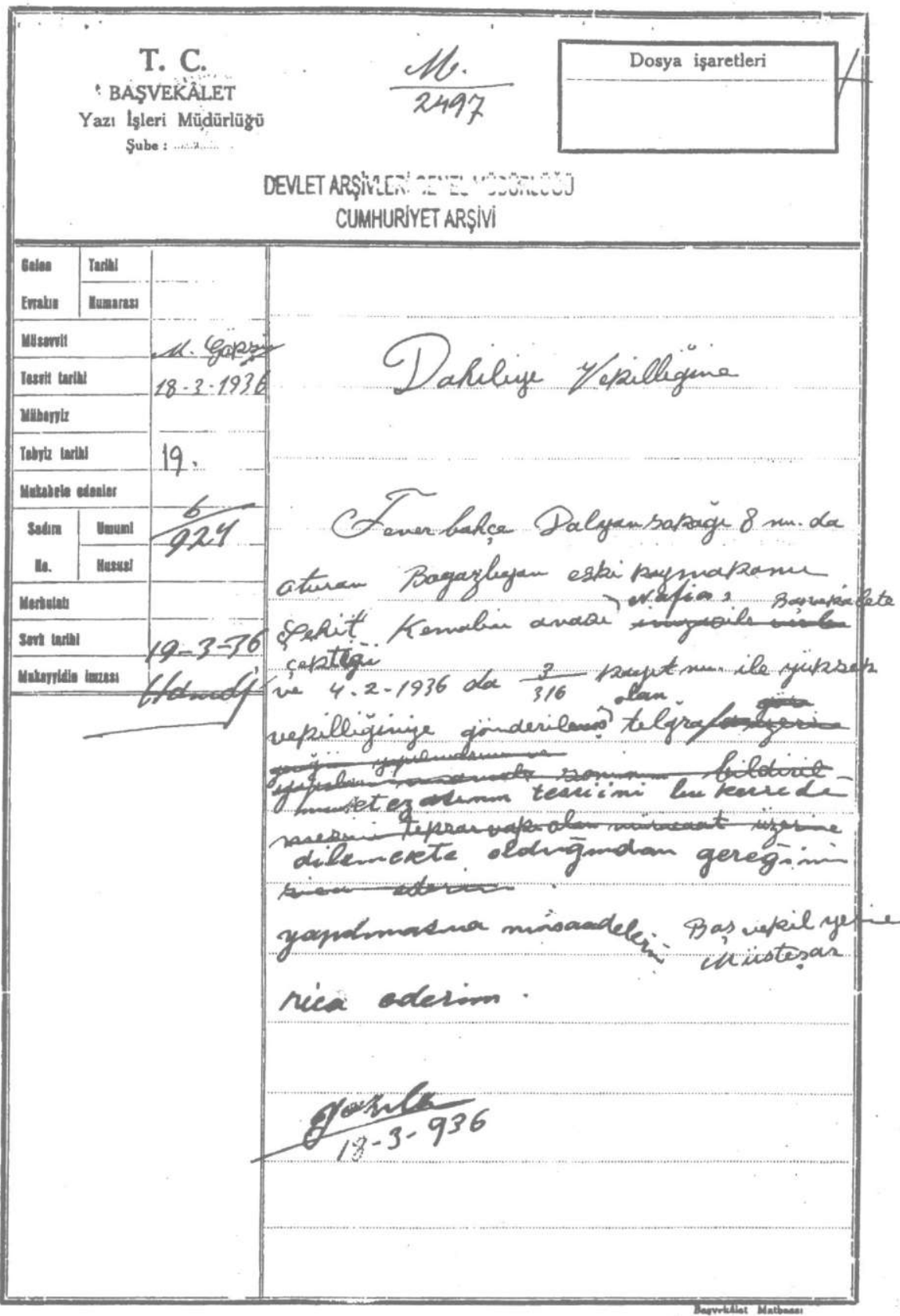

Ek 6- Boğazlıyan Kaymakamı Şehit Kemal'in Annesi Nafia Hanım'ın

Atatürk'e yazdığı dilekçesinin Başvekâlete havalesinden sonra sonucunu takip etmik için Başvekâlete verdiği dilekçe sonrasında Dahiliye Vekâletine dilekçenin akıbeti için yazılan Müsteşarın yazısının müsveddesi. Türkiye Cumhuriyeti, Başbakanlık Cumhuriyet Arşivi, No: 030. 18.01.01/23.7.19(1), eki 137-75 Taríh: 02.02.1927, Sayı: 4710 (6/924 sayı ve 18. 03. 1936 Tarihli müsvedde yazı). 


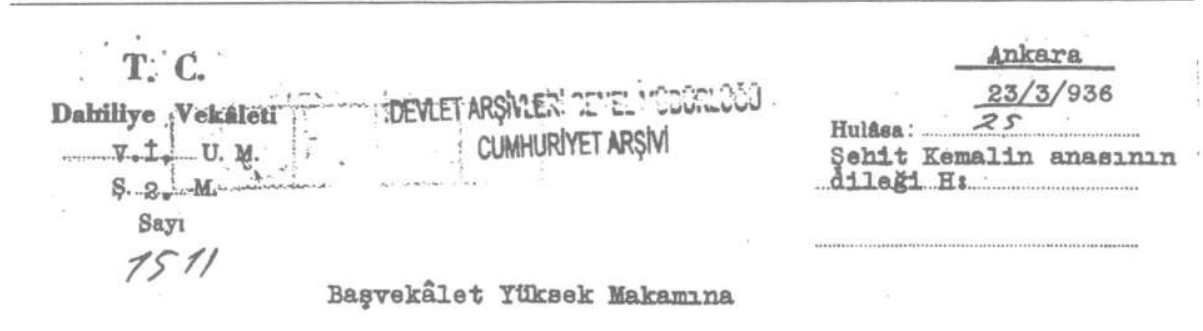

C. $19 / 3 / 936$ tarth ve 6/924 sayzl1 jazıya:

Fenerbahģe Dalyan sokak $8 \mathrm{~N} .1$ u evde oturan eskd Bograzl1yan kaymakam ģehtt Kemâlin annes1 Naflanin dilekçe日1, Kemalln alle ve goouklarzne Hijkimetģe yapilan yatimdan anasinen da 1atifade ettirilmesine miterett1p mamelensn yaplimari rloasigle $28 / 2 / 936$ tarth ve II77 sayll

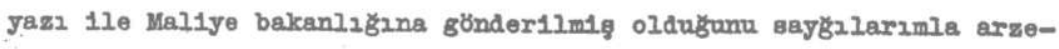
derim .

بand

I: Dah1liye vek111
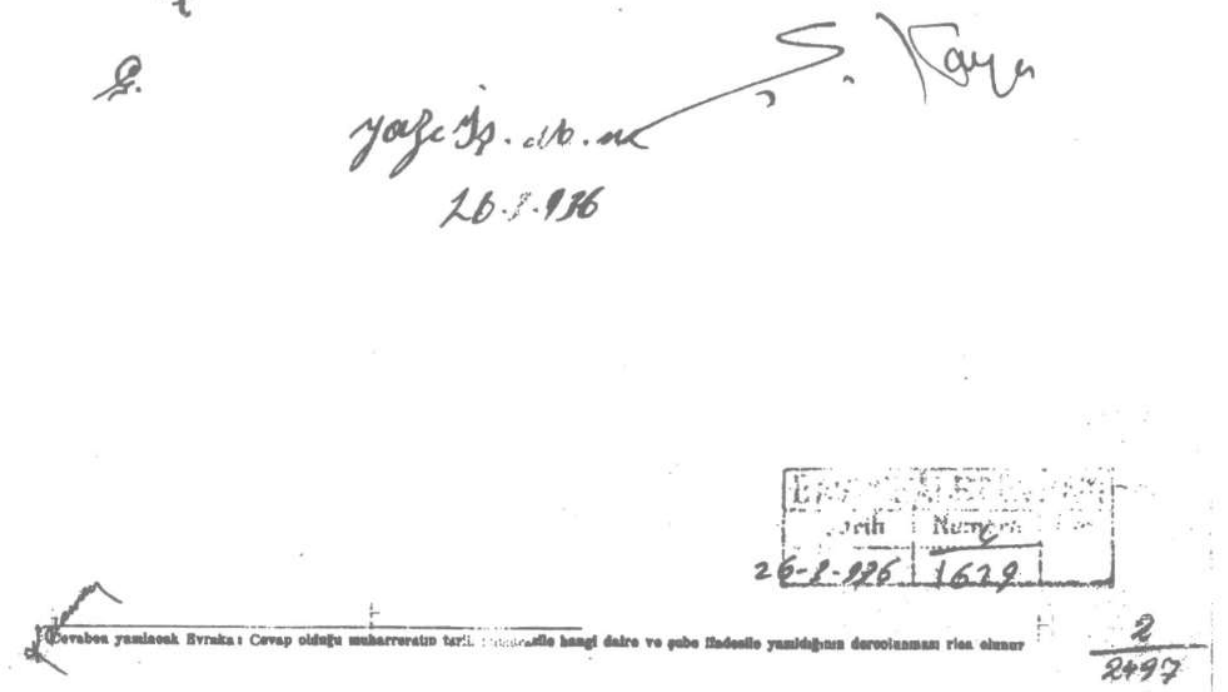

Ek 7- Boğazlıyan Kaymakamı Şehit Kemal'in Annesi Nafia Hanım'ın Dilekçesinin Dahiliye Vekâleti Tarafından Maliye Bakanlığına havale edildiğine dair Dahiliye Vekâletinden yazılan arz. Türkiye Cumhuriyeti, Başbakanlık Cumhuriyet Arşivi, No: 030. 18. 01. 01 / 23. 7. 19(1), eki 137-75 Tarih: 02. 02. 1927, Sayı: 4710 (Dahiliye Vekâletinin 23. 03. 1936 Tarihli Arzı). 


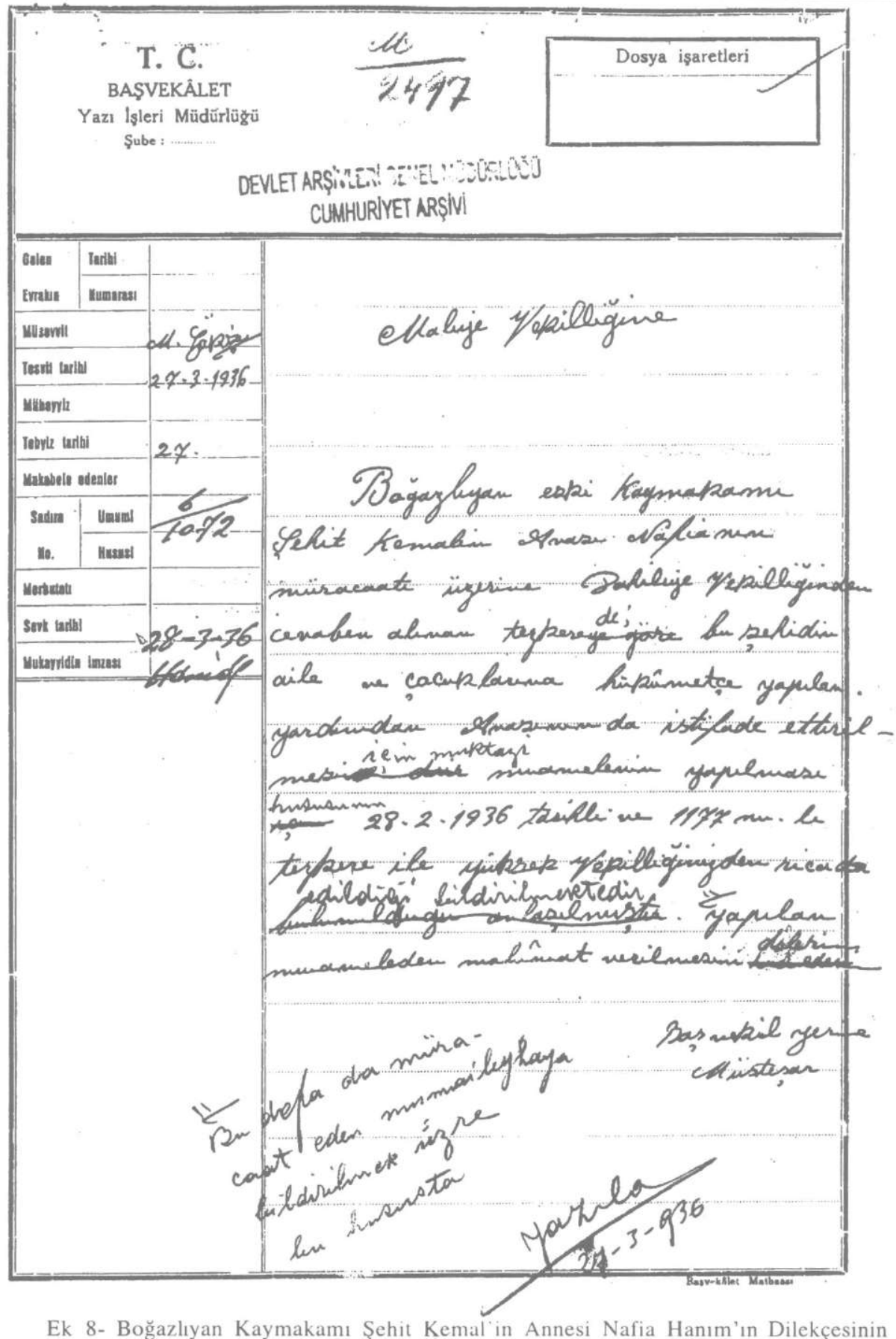

Ek 8- Boğazlıyan Kaymakamı Şehit Kemal'in Annesi Nafia Hanım'ın Dilekçesinin Maliye Vekâletine havalesinden sonra akıbetini öğrenmek için Başvekil Müsteşarının Maliye Vekâletine gönderilen yazısının müsveddesi. Türkiye Cumhuriyeti, Başbakanlık Cumhuriyet Arşivi, No: 030. 18.01.01/23. 7. 19(1), eki 137-75 Tarih: 02.02. 1927, Sayı: 4710 (27.03.1936 Tarihli Başvekil Yerine Müsteşar Adına yazılmış müsvedde yazı). 

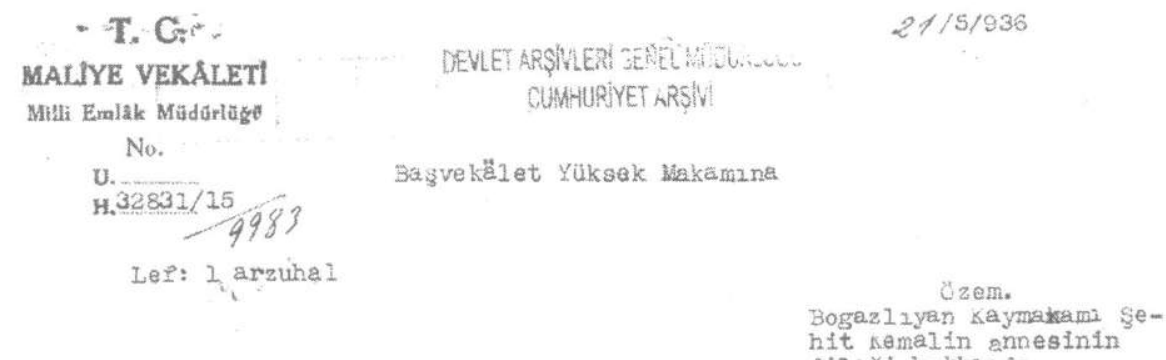
hit kemalin annesinin. dile ği hakklnca.

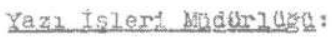

$27 / 3 / 936$ tarih ve $6 / 1072$ sayile yazllare karsilighadr. Bogazliyan kaymakami Shehit remalin emesi svifa tarafundan bittakdim Dahiliye vekâletỉe havale buyrulian ve taglluku haseblie hazineye gönderilen arzuhal tetkik olundu.

Dilek sahibi, ofiunun vefati sirasinda kocas $2 n i n$ hals vakt yeriride oldugundan ob̆lu ve ailesi epradina milletin bağgladı ğ mal

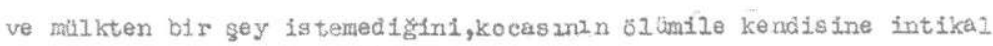
eden 28 liva dul maģnı n iages ine kàri gelned1 gini, ödenecek 700 line borcu bulunduğunt i.leri sürerek yarim talebinde bulunmaktadir. oglunur vefati alrasinda kendisi evli ve gayri mühta bulun-

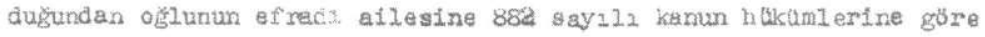
tahsis edilen envalder kendisire do hisso verilmesi mezkûs kanun hükumlerine wy gun degllet. Bu sebepten kerdisine mal tefviz edilmemis. id1.D1lek esasen mal fevvluzüna 1stihdaf stmeylp 700 lirelik borcunun tesviyesine medex olacak naktî bir yardimın yapulmas lna matuf bulunasina göre keyf yetin yaksok makamlarinca tayin ve takririne

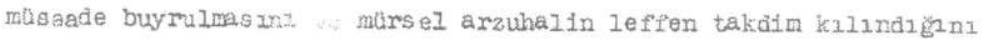
arzeylerim.

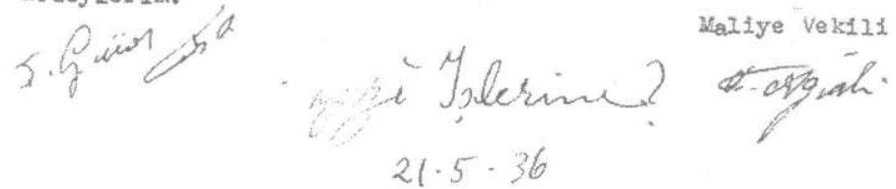

Ek 9- Boğazlıyan Kaymakamı Şehit Kemal'in Annesi Nafia Hanım'ın Dilekçesinin sonucunda Maliye Vekâletince alınan kararı Başvekâlete bildirir arz. Türkiye Cumhuriyeti, Başbakanlık Cumhuriyet Arşivi, No: 030. 18.01.01/23. 7. 19(1), eki 137-75 Tarih: 02. 02. 1927, Sayı: 4710 (21.05. 1936 Tarihli Maliye Vekili imzalı yazı). 
220

ERDAL AÇIKSES

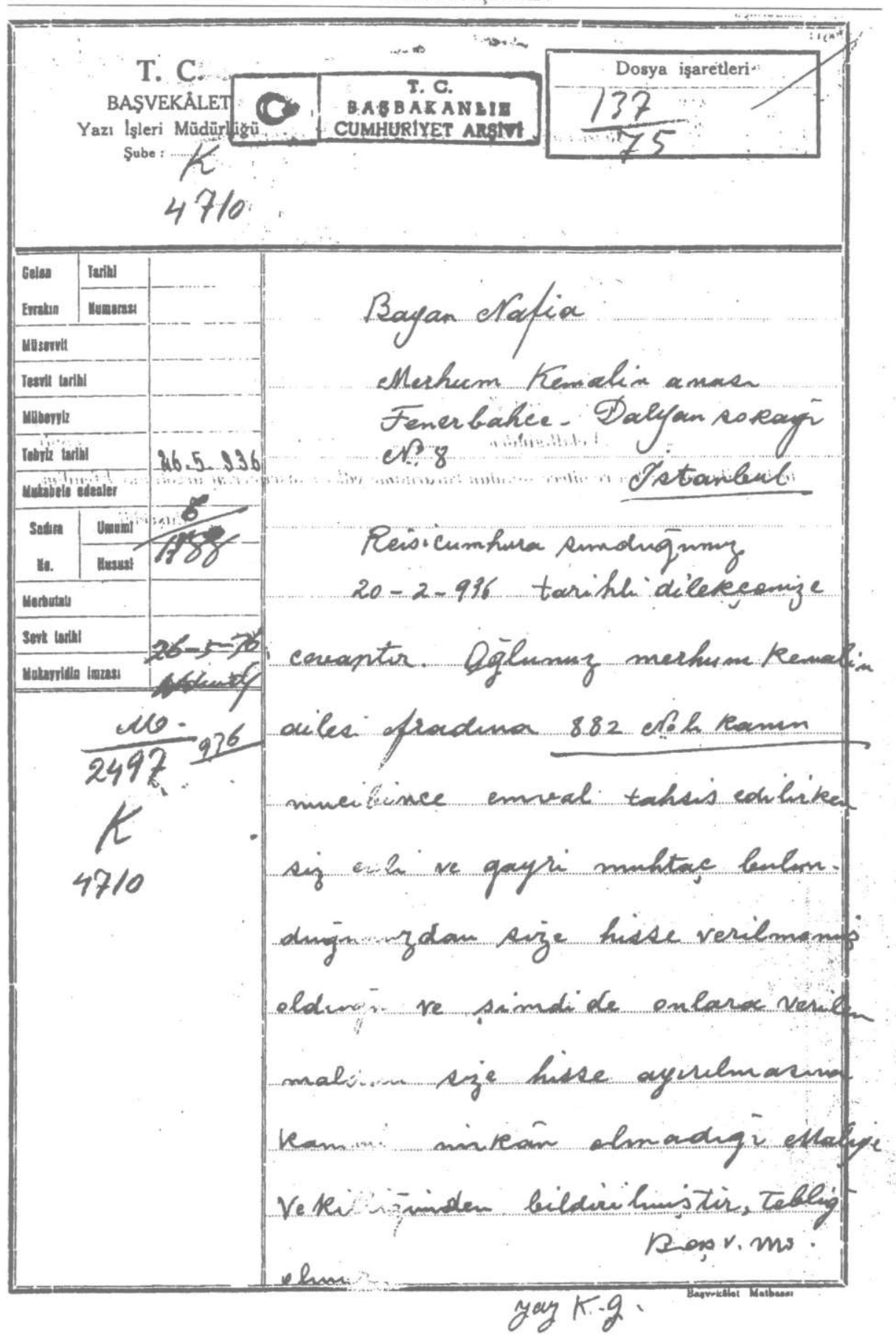

Ek 10- Maliye Vekâletince alınan kararı dorultusunda sonucun Nafia Hanıma tebliğ için Başvekâlet Müsteşarının kaleme aldığı yazı. Türkiye Cumhuriyeti, Başbakanlık Cumhuriyet Arşivi, No: 030. 18.01.01 / 23. 7. 19(1), eki 137-75 Tarih: 02. 02. 1927, Sayı: 4710 (6/1988 Sayı ve 26. 05. 1936 Tarihli Başviekil Müsteşarı adına yazılmaş müsvedde yazı). 